\title{
ライテング・フォトグラフ №.15
}

\section{宮城県・Star Light Fantasy SENDAI 光のページェント}

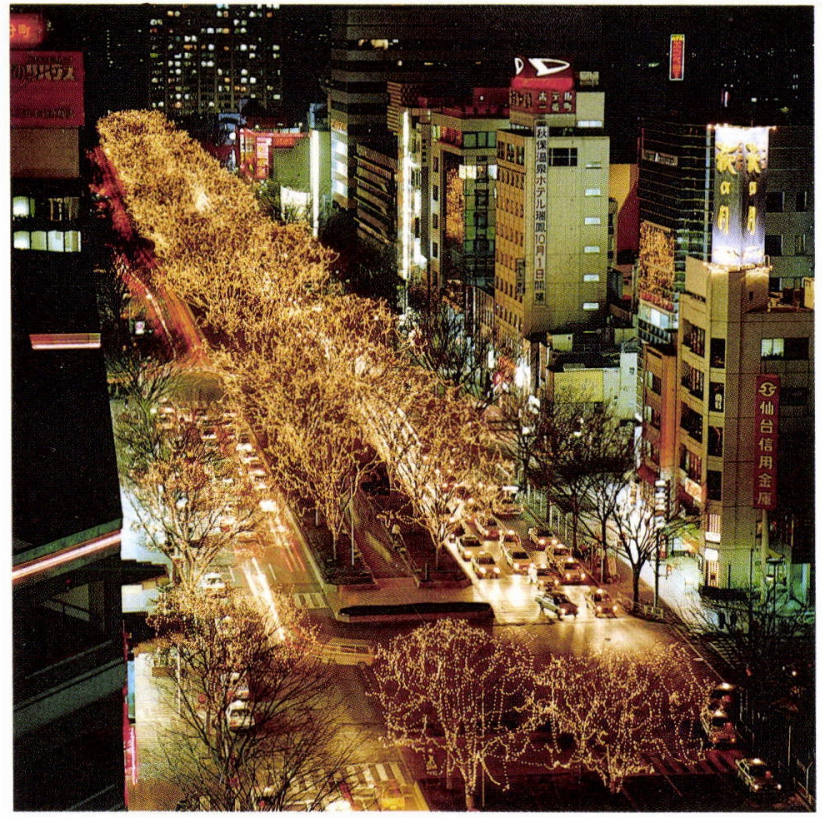

'88SENDAI光のページェント／通りをうめる イルミネーション

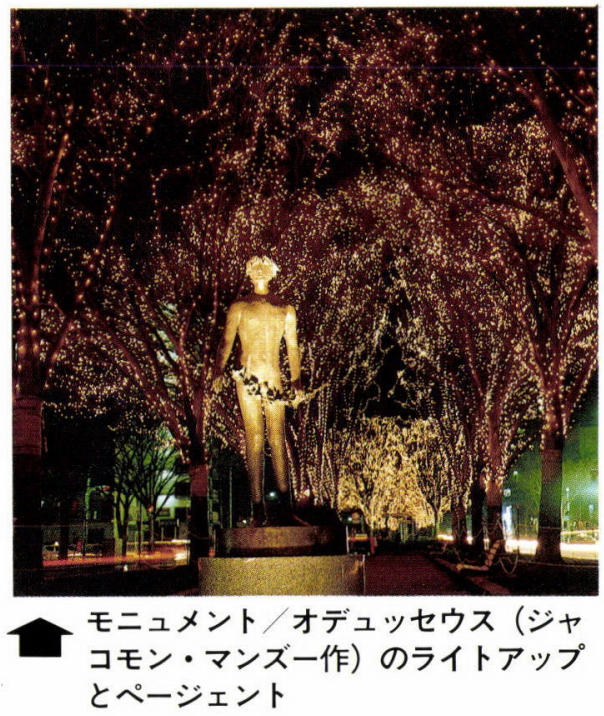

実施規模および設備概要

第 3 回目にあたる昭和63年の実施期間は，前年と同様 12 月12日から12月31日の大晦日までの 20 日間。

また，実施区間は仙台の定禅寺通りで $600 \mathrm{~m}(78$ 本一遊 歩道に 2 列）青葉通りで $1500 \mathrm{~m}$ (79本一中央分離带に 1 列) けやきに装飾されるイルミネーションは 1 本あたり約 3000 個，全体で45万個となっている.

照明設備については，契約は合計で $212 \mathrm{kVA}$ で, コード 付き白熱電球 $0.54 \mathrm{~W}$ をけやきの枝単位に敷設しており, こ の取付工事にのべ 800 名の人員と作業車延べ200台を要して いる.

J. Illum. Engng. Inst. Jpn. Vol. 73 No. 51989
概 要

『小さな光を見て，素直に美しいと感動したい．

そんな願いを，仙台で生まれ育った私たちみんなで

小さな光………それは，人間か明日，そして未来に託して の希望の光.

$$
\begin{aligned}
& 1 \text { 年に一度, 夢を見させてください. } \\
& \text { 私たちと私たちの子供たちのために。』 }
\end{aligned}
$$

を企画コンセプトにイルミネーションの持つ華やかさ，美 しさなどを人々の感性に訴之，仙台の『冬の風物詩』を全 国にアピールしていくという趣旨で昭和61年12月から S E NDAＩ光のページェントが実施されている.

昭和62年からは常設されたモ二ュメントのライトアッフ とイルミネーションが調和し，より玄想的な雾囲気を醇し だしており，夜の文化発展の可能性を示唆している。

またページェントを見ようと，近県からの観光客や帰省 客なども含め, 期間中約 120 万人以上の人出を数之，夏の

『仙台七夕』に匹敵するような賑わいをみせ，活気のある 街づくりの契機ともなっている。

実施にあたっては，地元商店街，行政，各企業，商工会 議所，青年会議所，大学，主婦などの『市民有志』により 実行委員会が組織され，費用についてもすべて趣旨に賛同 する市民や企業からの募金・協賛金で賄われており，いわ ば『市民手づくりのイベント』である。

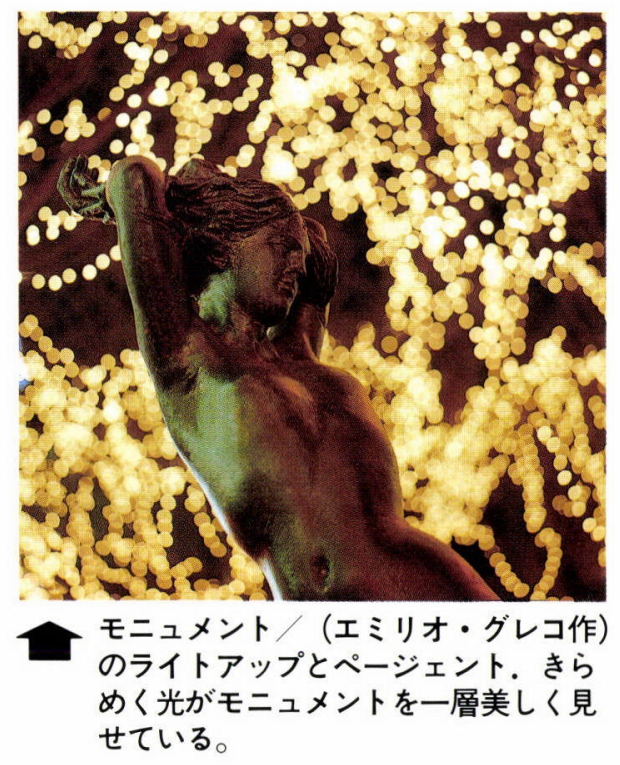

実施場所

施主 SENDAI光のページェント実行委員会 設計施工 東北電気工事(株) (資料提供 東北電力(侏) 正会員渡辺けい子 


\section{ライテング・フォトグラフ №.16}

一北 海 道一

\section{十勝中央大橋の景観・道路照明}

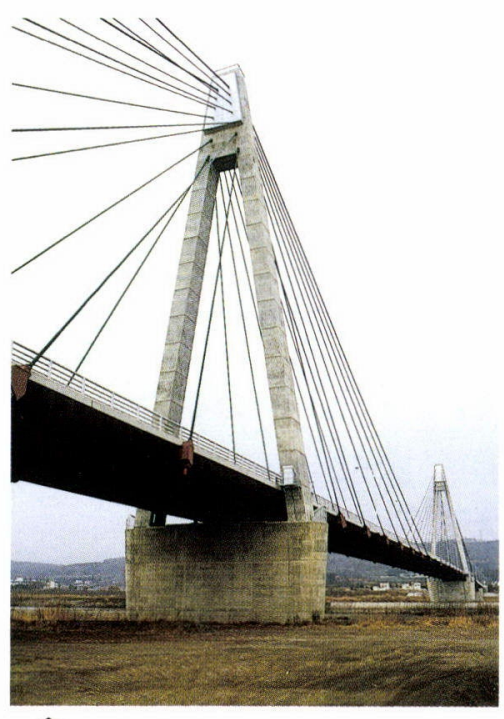

斜張塔

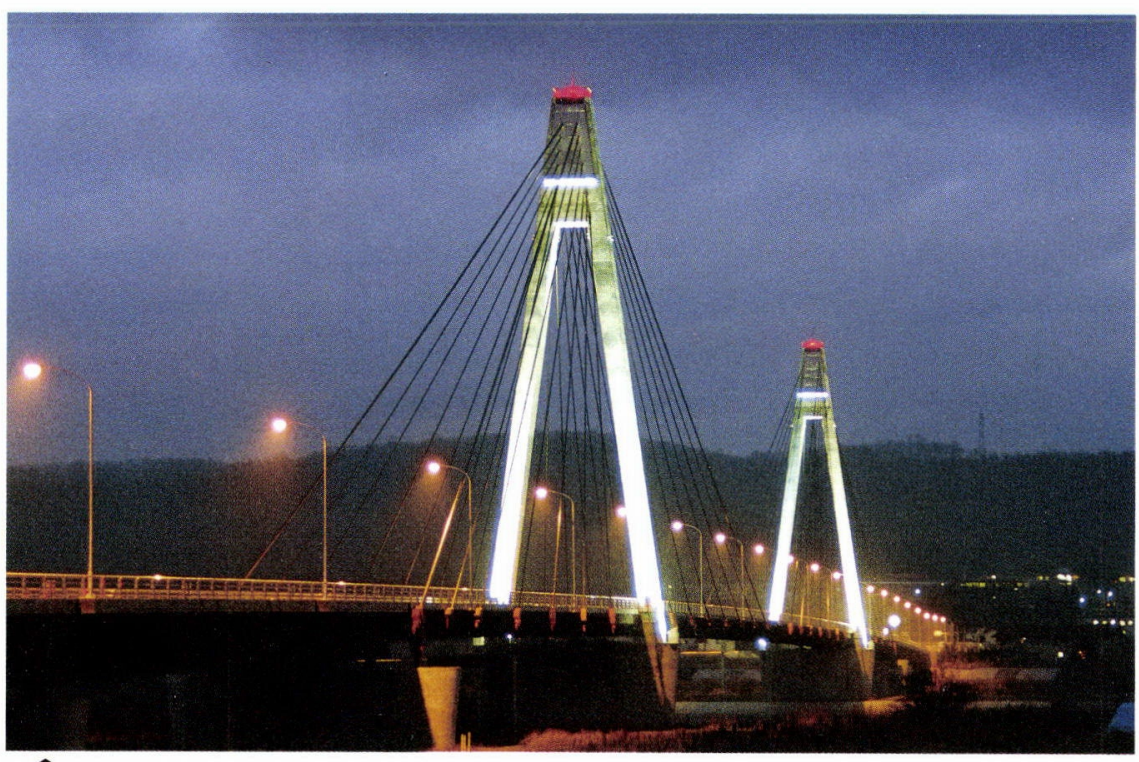

橋全景（夜間）

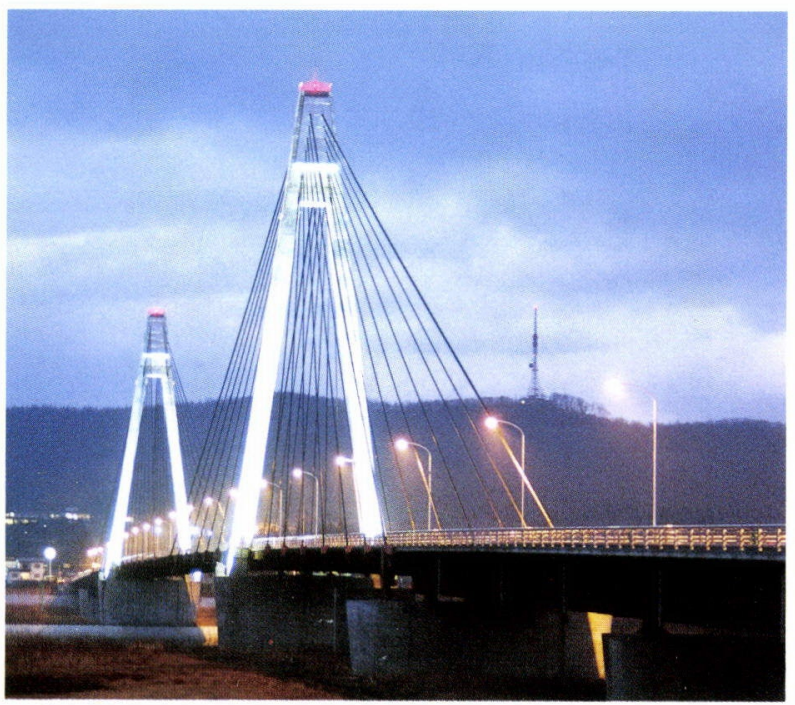

橋全景 (薄暮)

规 模 全長 $772.5 \mathrm{~m} の 2$ 本の塔による斜張橋

光 源 景観照明 $1000 \mathrm{~W}$ メルハライドランプ×12 道路照明 220 W高圧ナトリウムラン゙プ $\times 20$

器 具 景観照明 投光器内蔵の化粧ボックス器具 道路照明 道路照明器具 $(\mathrm{KSC}-4)$

照 度 景観照明 塔の鉛直面平均照度75 lx 道路照明 路面水平面照度 $15 \mathrm{~lx}$ (いずれも設計值)

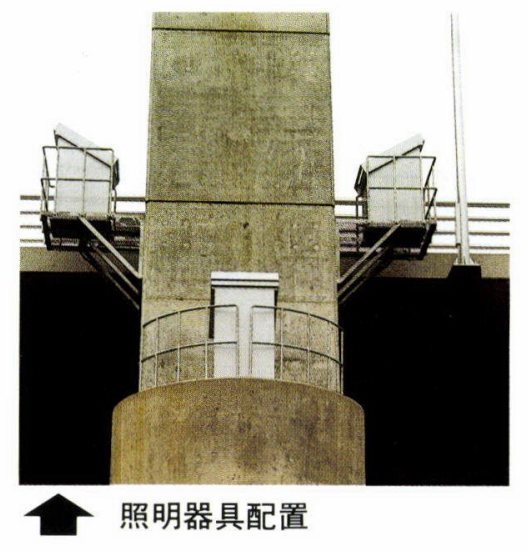

特良本施設は中央部分で逆 $\mathrm{V}$ 型の塔が 2 本立ちそこか ら斜めに伸ざるケーブルで橋を持ち上げる斜版楅 で塔と塔の間が $250 \mathrm{~m}$ と道内最大橋である。塔の

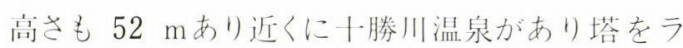
イトアップすることにより名物橋となった。

所在地

施 主 北海道十勝支方

施工带広(株振興電気

器具製作 和光電材機器(株)

竣 工 昭和 63 年 11 月

\section{(資料提供 和光電材機器濑)}

正会員 窝前典康 尃門会員 国友茂 